\title{
APPENDIX III
}

\section{附錄三}

\section{Exceptional Service Award / 特殊服務貢獻獎}

In 2017, three Exceptional Service Awards were granted to three recipients upon their retirement: two members of the Li Fang-Kuei Society Board of Directors and one member of the Bulletin of Chinese Linguistics.

Professor Hung-Nin Samuel Cheung rendered exceptional service to the Li Fang-Kuei Society for Chinese Linguistics from 2003 until his retirement in 2014:

As Executive Secretary of the Li Fang-Kuei Society for Chinese Linguistics (2008-2011) he carried out his responsibilities conscientiously and promptly, and always had the welfare of the Society in mind;

As Member of the Board of Directors (2003-2014) he devoted his time and energy to taking charge of the Li Fang-Kuei Society Book Award from its inception in 2006 until his retirement in 2014;

As an Editor-in-Chief cum overseer for the Bulletin of Chinese Linguistics, the professional journal of the Li Fang-Kuei Society for Chinese Linguistics, since its inception in 2005, he gave his whole-hearted support, discharged his duties promptly, and responded to questions quickly; he oversaw the Tenth Anniversary Volume of the Bulletin of Chinese Linguistics, Vols. 7.1 and 7.2, in 2013, in all $227+262$ pages, when it was published at the Center for Chinese Linguistics, Hong Kong University of Science and Technology, where he coordinated and supervised efforts with his former colleague Sun Jingtao and his former student Carine Yiu at the School of Humanities and Social Science there. That the volume was successfully compiled and published amidst economic turmoil at the Center for Chinese Linguistics, was due to his ceaseless efforts leading the Hong Kong University of Science and Technology team there.

Professor Ho Dah-An Member of the Academia Sinica rendered exceptional service to the Li Fang-Kuei Society for Chinese Linguistics from 2005 until his retirement in 2017:

As Member of the Board of Directors (2008-2017) he devoted his great talent to work for the achievement of the goals of the Society conscientiously, and he never hesitated to take up extra work and responsibilities while serving as Acting President of the Li Fang-Kuei Society for Chinese Linguistics from September through December 2016 when the President was on sick leave;

As an Editor-in-Chief of the Bulletin of Chinese Linguistics, the professional journal of the Li Fang-Kuei Society for Chinese Linguistics, since its inception in 2005, he gave whole-hearted support and discharged his duties promptly, even trying to persuade his Institute to act as publisher for this new journal, he acted as Guest Editor for a special issue of this journal, Volume 6, Number 1, with the topic Middle Chinese and After: Phonology, Lexicon and Dialects;

As chair of the Preparatory Committee for the Second Li Fang-Kuei Society Young Scholars Symposium held in 2018 at the Institute of Linguistics of the Academia Sinica in Nankang, Taiwan, he 
single-handedly spent an enormous amount of time and energy planning and managing all matters, drafting Invitation Letters to 28 senior scholars worldwide in the field of Chinese historical and comparative linguistics, soliciting nominations of promising young scholars for participation in the said Symposium, and assembling all application information including the curriculum vitae and research achievements of 90 candidates into a 157-page document of reference materials; his excellent work in organizing data and in providing a comprehensive account of what is involved in the preparation of the important task at hand, saved time and energy for the Board Members in their deliberation on the selection of the best-qualified candidates as participants for the planned Symposium.

Professor Zhang Min of The Hong Kong University of Science and Technology rendered exceptional service to the Li Fang-Kuei Society for Chinese Linguistics from 2006 through 2014:

As an Editor-in-Chief of the Bulletin of Chinese Linguistics, the professional journal of the Li Fang-Kuei Society for Chinese Linguistics, since its inception in 2005, he gave his whole-hearted support and discharged his duties promptly, he single-handedly designed the impressive cover and layout for the inaugural issue of the Bulletin of Chinese Linguistics in 2006, which has been followed ever since, he worked without sleep for many days to do all the copy-editing for this 304-page Issue, he continued to work closely and conscientiously with Samuel Hung-Nin Cheung and Anne O. Yue for this journal until he was no longer able;

On the occasion of the First Li Fang-Kuei Society Young Scholars Symposium held in 2013 at the University of Washington in Seattle, U.S.A. he responded to the call for urgent help that summer to see to all final tasks for the Symposium and journeyed from Hong Kong one week before the Symposium to help with various chores; he designed the beautiful Symposium Banner, which was used for the Second Li Fang-Kuei Society Young Scholars Symposium also; helped to assemble the Program Book with all the essays of the 19 Young Scholars; and delivered an excellent Keynote Speech on the second day of the Symposium, that aroused much interest from the Young Scholars in attendance. Without a doubt, he played an essential role in the resounding success of this First Symposium. 